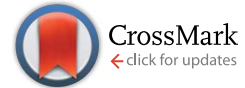

Cite this: RSC Adv., 2017, 7, 2913

Received 19th August 2016 Accepted 28th November 2016

DOI: 10.1039/c6ra20860f

www.rsc.org/advances

\section{Highly efficient magnetic hyperthermia ablation of tumors using injectable polymethylmethacrylate- $\mathrm{Fe}_{3} \mathrm{O}_{4}$}

\author{
Yi Ling, ${ }^{a}$ Xiuzhen Tang, ${ }^{a}$ Fengjuan Wang, ${ }^{a}$ Xiaohan Zhou, ${ }^{\text {a }}$ Ronghui Wang, ${ }^{a}$ \\ Liming Deng, ${ }^{a}$ Tingting Shang, ${ }^{a}$ Bing Liang, ${ }^{a}$ Pan Li, ${ }^{a}$ Haitao Ran, ${ }^{a}$ Zhigang Wang, ${ }^{a}$ \\ Bing $\mathrm{Hu}^{\mathrm{b}}$ Chunhong $\mathrm{Li}^{\star{ }^{*} \mathrm{c}}$ Guoqing Zuo*a and Yuanyi Zheng ${ }^{\star a b}$
}

Magnetic hyperthermia is a promising minimally invasive technique for tumor therapy which has drawn much attention. However, the currently used magnetic materials have their limitations. In this study, we developed an injectable, liquid to solid phase transitional magnetic material, polymethylmethacrylate (PMMA) $-\mathrm{Fe}_{3} \mathrm{O}_{4}$ designed for highly efficient magnetic hyperthermia ablation of tumors. The PMMA$\mathrm{Fe}_{3} \mathrm{O}_{4}$ was prepared by the incorporation of $\mathrm{PMMA}$ and the $\mathrm{Fe}_{3} \mathrm{O}_{4}$. The morphology characterization, the magnetic properties and the heating efficiency of $\mathrm{PMMA}-\mathrm{Fe}_{3} \mathrm{O}_{4}$ were studied. The $\mathrm{Fe}_{3} \mathrm{O}_{4}$ particles were evenly distributed in the PMMA and the hysteresis curve of $\mathrm{Fe}_{3} \mathrm{O}_{4}$ and $\mathrm{PMMA}-\mathrm{Fe}_{3} \mathrm{O}_{4}$ indicated that they were magnetic materials. When exposed to an alternating current magnetic field in vitro, the magnetic $\mathrm{PMMA}-\mathrm{Fe}_{3} \mathrm{O}_{4}$ generated heat. The increased temperature of excised bovine liver was positively correlated to the iron content and time, which suggested that the temperature inside the tumor was

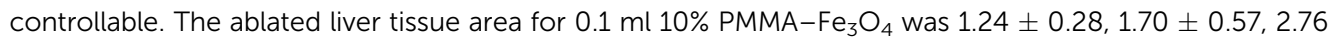
$\pm 0.31,4.17 \pm 1.07 \mathrm{~cm}^{3}$, respectively, at $60,120,180$ and $240 \mathrm{~s}$ time points. In the in vivo animal experiments, a MB-231 breast cancer xenograft model was obtained in nude mice. In this tumor model, $\mathrm{PMMA}-\mathrm{Fe}_{3} \mathrm{O}_{4}$ was injected precisely using guided ultrasound imaging. After the injection, the computer tomography images showed that it was well confined in the tumor tissues without any leakage. The

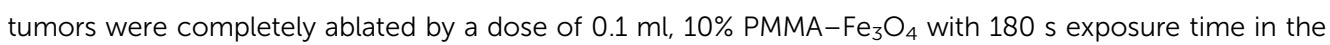
magnetic field. Our results demonstrated that $\mathrm{PMMA}-\mathrm{Fe}_{3} \mathrm{O}_{4}$ was an excellent magnetic material for the localized magnetic hyperthermia ablation of tumors.

\section{Introduction}

Cancer is a major public health problem in the world ${ }^{\mathbf{1}}$ and the incidence of cancer has increased with the arrival of aging and augmented standards of living., ${ }^{2,3}$ For most cancer patients, surgical treatment is often the first choice, though surgical resection has limitations and potential complications. ${ }^{4}$ Thus, minimally invasive techniques such as radio-frequency ablation, microwave ablation and high intensity focused ultrasound (HIFU) has aroused more and more concerns. ${ }^{5}$ However, they have their limitations as well. For example, HIFU is affected by gas and bone, microwave ablation is not very suitable for deep tumor ablation, and the needle used for radio-frequency ablation is too big, which might cause potential safety problems. ${ }^{6,7}$

${ }^{a}$ Second Affiliated Hospital of Chongqing Medical University, Chongqing Key Laboratory of Ultrasound Molecular Imaging, Chongqing 400016, China

${ }^{b}$ Shanghai Institute of Ultrasound in Medicine, Shanghai Jiaotong University Affiliated Shanghai Sixth People's Hospital, Shanghai 200233, China

${ }^{c}$ School of Metallurgy and Materials Engineering of Chongqing University Science and Technology, Chongqing 401331, China
Magnetic hyperthermia is an adjuvant in cancer treatment that is used to improve the treatment effects. ${ }^{8}$ A temperature range of $41-43{ }^{\circ} \mathrm{C}$ is employed for most of the hyperthermia therapy. ${ }^{9}$ The physical principle of magnetic heating is owed to the Brownian and Neel relaxation, ${ }^{\mathbf{1 0}}$ which is not affected by gas or bone and is suitable for both superficial and deep tumor ablation. Thus, the technique of magnetic hyperthermia develops very fast and has been applied in clinic already. ${ }^{\mathbf{1 1 2}}$ The magnetic media is the key factor for magnetic hyperthermia, which includes magnetic nanoparticles, magnetic fluid and ferromagnetic thermoseeds. ${ }^{\mathbf{1 3}, \mathbf{1 4}}$ For magnetic fluid or magnetic nanoparticles, it is difficult to selectively accumulate in tumor tissue $^{15,16}$ and can easily leak into the surrounding tissues or blood vessel, which might cause potential safety problems and decrease the therapy efficiency. Ferromagnetic thermoseeds need precision and are relatively big, complex calculating and controlling. ${ }^{17}$ Recently, Chunyan $\mathrm{Xu}^{18}$ reported a novel material, the calcium phosphate cement (CPC) containing $\mathrm{Fe}_{3} \mathrm{O}_{4}$, as an injectable and biodegradable media for the ablation of tumor. This material could form a solid implant inside the tumor to decrease the $\mathrm{Fe}_{3} \mathrm{O}_{4}$ leakage from the tumor to the surrounding 
tissues. However, the setting time ${ }^{\mathbf{1 9}}$ for CPC is $30-60$ minutes $^{\mathbf{2 0}}$ and the relatively long setting time might permit some of the $\mathrm{Fe}_{3} \mathrm{O}_{4}$ particles leak into the surrounding tissues before the liquid material transform to solid implant.

Bearing these limitations in mind, to develop an injectable magnetic media with a faster liquid to solid phase transformation time and without losing the other advantages of CPC is of importance. Polymethylmethacrylate (PMMA) is a material approved by FDA for clinical use. It has good compressive strength, safety and biocompatibility records, which has attracted wide publicity ${ }^{21}$ and has been used in orthopedic surgery and trauma for fixing arthroplasties. ${ }^{22,23}$ Moreover, PMMA possesses an ability to transform from liquid to solid state in a much shorter time than CPC (the setting time of PMMA is $12.5 \pm 1$ minute). ${ }^{24,25}$ We supposed the magnetic media made from PMMA might confine the $\mathrm{Fe}_{3} \mathrm{O}_{4}$ nanoparticles well in the tumor tissue after injection, which should further improve the treatment efficiency of hyperthermia ablation of tumor.

After a careful review of the literature, we found M. Kawashita has already tested the magnetic heating efficiency of the PMMA containing $\mathrm{Fe}_{3} \mathrm{O}_{4}$ in vitro. The temperature of $\mathrm{PMMA}-\mathrm{Fe}_{3} \mathrm{O}_{4}$ could be increased rapidly to over $70{ }^{\circ} \mathrm{C}$ within a period of several tens of seconds ${ }^{25}$ and they thought PMMA- $\mathrm{Fe}_{3} \mathrm{O}_{4}$ could be used for high efficient cancer hyperthermia therapy. Unfortunately, they had not tested $\mathrm{PMMA}-\mathrm{Fe}_{3} \mathrm{O}_{4}$ for cancer treatment neither in vitro cell experiments nor in vivo animal model experiments.

In this study, the injectable and fast liquid-solid phase transitional $\mathrm{PMMA}-\mathrm{Fe}_{3} \mathrm{O}_{4}$ was prepared and its high efficiency for tumor hyperthermia therapy was studied in vivo.

\section{Experimental section}

\subsection{Preparation of $\mathrm{PMMA}-\mathrm{Fe}_{3} \mathrm{O}_{4}$}

$\mathrm{Fe}_{3} \mathrm{O}_{4}$ powder (Chengdu Aike reagent, China) with an average diameter of 20-50 nm, PMMA powder and MMA liquid (Heraeus, Germany) were used. Four kinds of cement were prepared by mixing the PMMA, MMA liquid with the different proportion of iron oxide. The weight ratio of PMMA and MMA liquid was 2/3 (Table 1). ${ }^{26}$

\subsection{Structure characteristics of $\mathrm{PMMA}-\mathrm{Fe}_{3} \mathrm{O}_{4}$}

The microstructure of PMMA- $\mathrm{Fe}_{3} \mathrm{O}_{4}$ was tested using scanning electron microscope (SEM, JEOC-7800F) and the element analysis was observed by an energy dispersive X-ray spectrometer $\left(\mathrm{EDS}, \mathrm{x}-\mathrm{Max}^{\mathrm{N}}\right)$.

Table 1 Composition of PMMA- $\mathrm{Fe}_{3} \mathrm{O}_{4}$

\begin{tabular}{llll}
\hline & \multicolumn{2}{l}{ Powder (wt\%) } & \\
\cline { 2 - 3 } Cement & $\mathrm{Fe}_{3} \mathrm{O}_{4}$ & PMMA & Liquid (wt\%) \\
\hline PMMA-0 & 0 & 40 & 60 \\
PMMA-5c & 5 & 38 & 57 \\
PMMA-10c & 10 & 36 & 54 \\
PMMA-15c & 15 & 34 & 51
\end{tabular}

\subsection{Magnetic properties of the $\mathrm{Fe}_{3} \mathrm{O}_{4}$ and PMMA-Fe $\mathrm{O}_{3} \mathrm{O}_{4}$ powder}

PMMA- $\mathrm{Fe}_{3} \mathrm{O}_{4}$ was prepared by PMMA and $\mathrm{Fe}_{3} \mathrm{O}_{4}$ nanoparticles. The magnetic properties of $\mathrm{Fe}_{3} \mathrm{O}_{4}$ and PMMA- $\mathrm{Fe}_{3} \mathrm{O}_{4}$ powder were tested by Physical Property Measurement System (PPMS-9) at room temperature. PPMS was developed by Quantum Design which can be used to measure the basic physical properties of materials. $^{27}$

\subsection{Injectability}

The liquid PMMA- $\mathrm{Fe}_{3} \mathrm{O}_{4}$ was poured into a $2 \mathrm{ml}$ syringe. Then, the PMMA- $\mathrm{Fe}_{3} \mathrm{O}_{4}$ was injected into the water to observe the progress of liquid-solid phase transformation.

\subsection{Heating efficiency in excised bovine liver}

PMMA- $\mathrm{Fe}_{3} \mathrm{O}_{4}$ with different iron contents were prepared into 6 $\mathrm{mm}$ diameter balls and dried for $24 \mathrm{~h}$. They were embedded into the excised bovine liver pieces $(2.5 \mathrm{~cm} \times 2 \mathrm{~cm} \times 2 \mathrm{~cm})$ and exposed to the altering current magnetic field generated by a homemade magnetic hyperthermia machine (frequency 626 $\mathrm{kHz}$, output current $28.6 \mathrm{~A}$, coil diameter $3 \mathrm{~cm})^{28}$ for $300 \mathrm{~s}$ at room temperature. The surface temperature of $\mathrm{PMMA}-\mathrm{Fe}_{3} \mathrm{O}_{4}$ was acquired by a far-infrared thermometer (Fluke Ti32, Fluke Corporation, USA). The thermal images were analyzed using the Smart View 3.6 software. During treatment and measurement period, liver piece did not show significant shrinkage.

According to the above experiments, the 10\% PMMA (PMMA10c) was the best choice for next experiment. $0.1 \mathrm{ml}$ PMMA-10c was shaped into balls and dried for $24 \mathrm{~h}$. They were implanted into the excised bovine liverpieces $(2.5 \mathrm{~cm} \times 2 \mathrm{~cm} \times 2 \mathrm{~cm})$ and exposed to the same altering current magnetic field for 60,120 , 180 and $240 \mathrm{~s}$. Then, the excised bovine liver was split into 2 parts and the coagulation necrosis area was measured by ruler. Based on the following formula, the area was calculated.

$$
S_{1}=\pi D_{1} D_{2}
$$

where $S_{1}$ is the coagulation necrosis area $\left(\mathrm{cm}^{2}\right), D_{1}$ and $D_{2}(\mathrm{~cm})$ is the long and short diameter.

\subsection{MB-231 human breast cancer xenograft in nude mice}

Nine female nude mice ( 4 weeks old, $19.3 \pm 0.8 \mathrm{~g}$ ) were selected randomly. MB-231 breast cancer cells were collected by centrifugation, dispersed into DMEM cell culture medium and $1 \times 10^{5}$ cells were injected into the back of each nude mouse subcutaneously. After 4 weeks, the tumor volume reached to $0.453 \pm 0.109 \mathrm{~cm}^{3}$ which were used to the next experiment. Animals were maintained in accordance with the guidelines of the Ministry of Science and Technology of Health Guide for Care and Use of Laboratory Animals, China, and approved by the institutional ethical committee (IEC) of Second Affiliated Hospital of Chongqing Medical University. Based on the following formula, the tumor volume was calculated. ${ }^{29}$

$$
V_{1}=D_{1} D_{2}^{2} / 2
$$


where $V_{1}$ is the tumor volume $\left(\mathrm{cm}^{3}\right), D_{1}$ and $D_{2}(\mathrm{~cm})$ is the long and short diameter.

\subsection{Nude mice MB-231 human breast cancer xenograft}

The 9 nude mice were divided into two groups. For group 1,6 nude mice were selected randomly and were anesthetized by pentobarbital (0.1-0.18 ml/mouse, 1\%). $0.1 \mathrm{ml}$ PMMA-10c was injected into the tumor tissues under the real time ultrasound induction (Esoate, L5-12 MHz). After that, CT images (Quantum FX) were acquired to observe the position of PMMA-10c. Then, the nude mice were exposed to the altering current magnetic field for $180 \mathrm{~s}$ and the surface temperature of tumor was obtained by infrared thermometer. To acquire the microstructure of ablated tumors, 3 nude mice were euthanized in $24 \mathrm{~h}$ after treatment. For group 2, 3 nude mice as control group had no treatment.

\section{Results}

\subsection{Characteristic of $\mathrm{PMMA}-\mathrm{Fe}_{3} \mathrm{O}_{4}$}

As showed in the SEM images [Fig. 1(a)], the $\mathrm{Fe}_{3} \mathrm{O}_{4}$ nanoparticles were evenly distributed in PMMA. The element mapping of PMMA-Fe $\mathrm{O}_{3}$ [Fig. 1(b)] showed that every element was well dispersed in PMMA and the corresponding molecular percentages for C, O and Fe were 48.64, 40.90, 10.46, respectively, [Fig. 1(c)].

\subsection{Injectability}

Fig. 2(a-f) illustrated that liquid PMMA- $\mathrm{Fe}_{3} \mathrm{O}_{4}$ could be injected from syringe (the inner diameter of needle: $1.2 \mathrm{~mm}$ ). When contacted with water, $\mathrm{PMMA}-\mathrm{Fe}_{3} \mathrm{O}_{4}$ would not be defeated and dispersed. The liquid-solid phase transformation happened after setting time.

\subsection{Magnetic properties}

The hysteresis curve (Fig. 3) showed that the pure $\mathrm{Fe}_{3} \mathrm{O}_{4}$ nanoparticles and the PMMA- $\mathrm{Fe}_{3} \mathrm{O}_{4}$ were ferromagnetic. The saturation magnetization value $\left(M_{\mathrm{s}}\right)$ and the coercive force $\left(H_{\mathrm{c}}\right)$ for the pure $\mathrm{Fe}_{3} \mathrm{O}_{4}$ nanoparticles were $-15.3 \mathrm{emu} \mathrm{g}^{-1}$ and 126.9 Oe. However, the PMMA- $\mathrm{Fe}_{3} \mathrm{O}_{4}$ had an $M_{\mathrm{s}}$ of -0.3 emu g ${ }^{-1}$ and an $H_{\mathrm{c}}$ of 64.5 Oe.
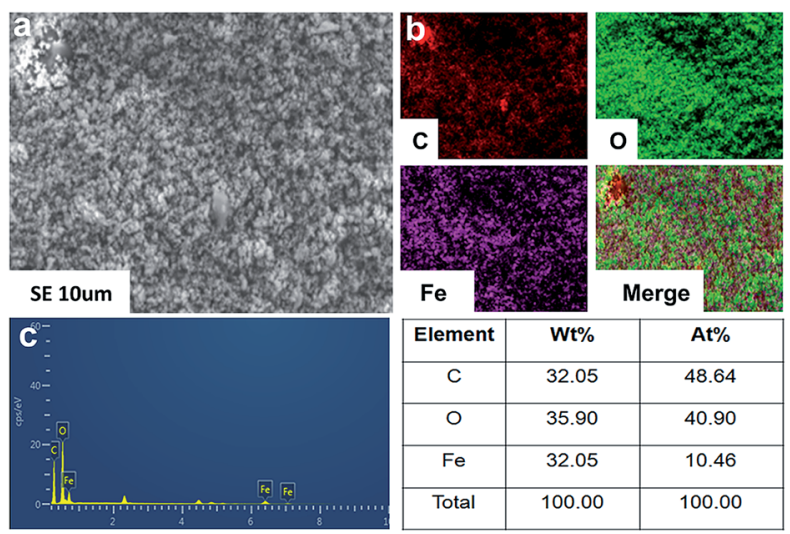

Fig. 1 (a) SEM photographs; (b) and (c) corresponding EDS map scan images for the $\mathrm{PMMA}-\mathrm{Fe}_{3} \mathrm{O}_{4}$.
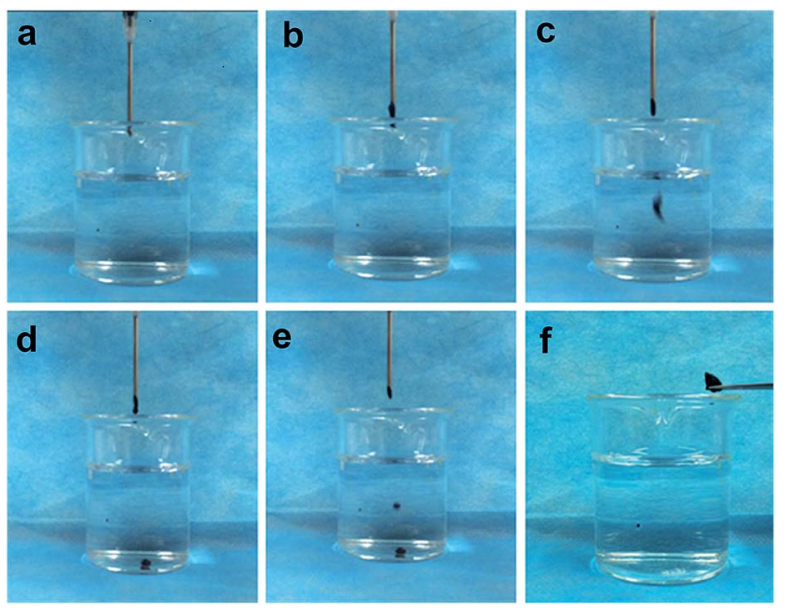

Fig. 2 The process of liquid-solid phase transformation; (a) before the injection; $(b-e)$ injecting liquid $\mathrm{PMMA}^{-} \mathrm{Fe}_{3} \mathrm{O}_{4}$ through a needle; ( $\mathrm{f}$ ) after the injection. The $\mathrm{PMMA}-\mathrm{Fe}_{3} \mathrm{O}_{4}$ transformed into solid implant which could be taken out by a tweezers.

\subsection{Heating efficiency in vitro}

Fig. 4(a) showed that the surface temperature of 0.1 ml PMMA10c in excised bovine liver increased with the iron contents and time. But for the control group, the temperature of pure PMMA was not changing with the time. The corresponding timetemperature curve [Fig. 4(b)] showed that the surface temperature of PMMA-10c was $44.20 \pm 1.13,51.65 \pm 1.62,56.25 \pm$ $1.2{ }^{\circ} \mathrm{C}$, respectively, at the time point of 60,180 and $300 \mathrm{~s}$. While the surface temperature of $5 \%$ PMMA- $\mathrm{Fe}_{3} \mathrm{O}_{4}$ (PMMA-5c) and $15 \%$ PMMA- $\mathrm{Fe}_{3} \mathrm{O}_{4}$ (PMMA-15c) were $30.70 \pm 1.153,35.83 \pm$ $0.87,38.60 \pm 1.51{ }^{\circ} \mathrm{C}$ and $59.25 \pm 2.19,73.15 \pm 0.49,79.70 \pm$ $2.40{ }^{\circ} \mathrm{C}$, at the time point of 60,180 and $300 \mathrm{~s}$. After being exposed to the altering current magnetic field, the heat generated by the PMMA-10c embedded inside the excised bovine liver changed the color of the surround tissue from a dark red color into a pale white color [Fig. 4(c)]. The coagulation necrosis areas for $0.1 \mathrm{ml}$ PMMA-10c were $1.24 \pm 0.23,1.70 \pm 0.57,2.76 \pm 0.31$, $4.17 \pm 1.07 \mathrm{~cm}^{2}$, respectively, at the time points of $60,120,180$ and $240 \mathrm{~s}$ [Fig. 4(d)].

\subsection{Heating efficiency in vivo}

The ultrasound images [Fig. 5(a)] showed that the echo of the tumor was hypoechoic. The hyperechoic needle was clearly visible in ultrasound imaging which guaranteed the precisely injection of PMMA- $\mathrm{Fe}_{3} \mathrm{O}_{4}$ into the tumor. After injection, the PMMA- $\mathrm{Fe}_{3} \mathrm{O}_{4}$ appeared hyperechoic inside the tumor tissue. The CT images [Fig. 5(b)] illustrated that PMMA-10c with high intensity inside the tumor. The thermal images [Fig. 5(c)] showed that the surface temperature of the tumor increased with the time when exposed to the altering current magnetic field and reached to $53.05 \pm 3.18^{\circ} \mathrm{C}$ at $180 \mathrm{~s}$ [Fig. 5(d)].

The macroscopic image [Fig. 6(a)] showed the tumor volume was changing with the time after the magnetic hyperthermia ablation in vivo. After the ablation of the tumor for $180 \mathrm{~s}$, the color of the skin on the tumor turned into a pale color 

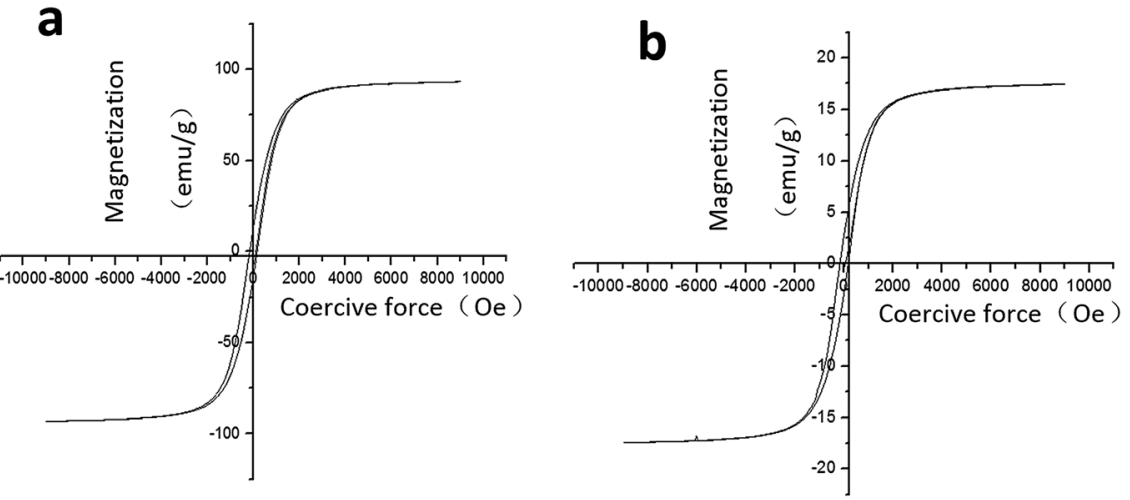

Fig. 3 (a) The hysteresis curve of pure $\mathrm{Fe}_{3} \mathrm{O}_{4}$ nanoparticles; (b) the hysteresis curve of $\mathrm{PMMA}-\mathrm{Fe}_{3} \mathrm{O}_{4}$.

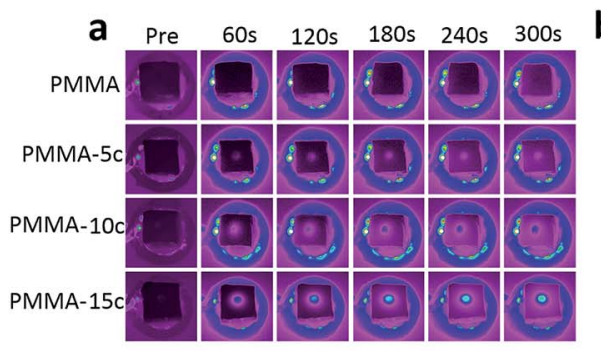

b

C

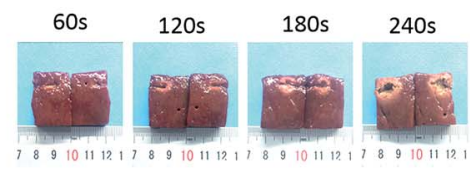

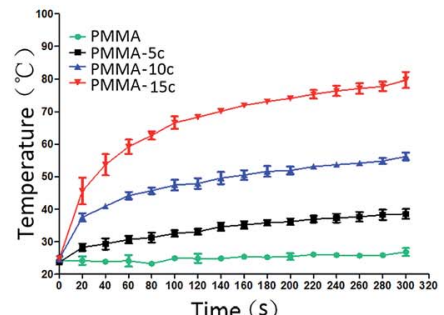

Time (s)

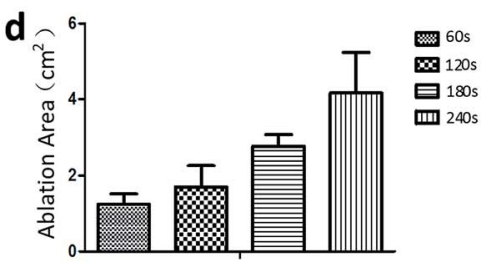

Fig. 4 (a) The thermal images of the PMMA- $\mathrm{Fe}_{3} \mathrm{O}_{4}$ with different iron contents at different magnetic induction time point (the pure PMMA was taken as the control group); (b) the corresponding time-temperature curve of $\mathrm{PMMA}-\mathrm{Fe}_{3} \mathrm{O}_{4}$; (c) macroscopic photos of excised bovine liver (the tissue with a pale white color around the PMMA-10c was the coagulation necrosis tissue); (d) the corresponding coagulation necrosis area.

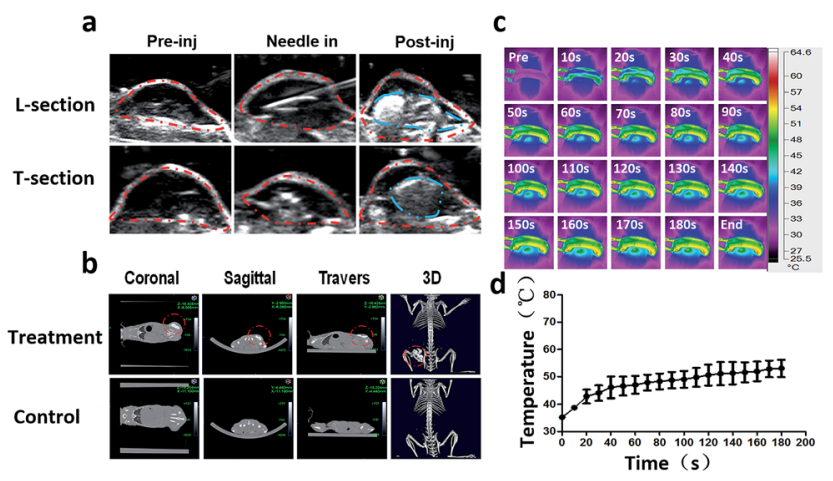

Fig. 5 (a) $0.1 \mathrm{ml}$ PMMA-10c was injected into the tumor under real time guidance of ultrasound imaging. The ultrasound images showed the procedures for injection at two different sections ( $L$ section: longitudinal section, T section: transverse section, Pre inj: pre injection, Post inj: post injection, the red dotted line: tumor, the blue dotted line: PMMA-10c); (b) CT images of PMMA-10c (red dotted line: PMMA$\mathrm{Fe}_{3} \mathrm{O}_{4}$ ); (c) the thermal imaging of the tumor was exposed to the altering current magnetic field for $180 \mathrm{~s}$ after injection; (d) the corresponding time-temperature curve. immediately. On the first day, the color of the skin on the tumor gradually turned from pale color into black color, and a boundary between the ablated tissue and the non-ablated tissue could be clearly observed. On the third day, the tumor tissue began to form a scab and on the tenth day, the scab began to desquamate. Until the fifteenth day, the scab separated from mice and fell down. Corresponding time-tumor volume curve was showed in [Fig. 6(b)], which revealed that tumor volume decreased with the time after treatment. While in the control group, the tumor volume had an upward tendency. Fig. 6(c) showed that the whole body weights of the mice didn't change with the time. The pathology images showed there was a significant difference between the ablated and non-ablated tumor tissue [Fig. 6(d)]. It could be observed from the tumor tissue that received PMMA-10c followed by ablation that disorder tissue with distinct destructed cells existed. On the other hand, an integrated nucleus and cytoplasm was found in the control group while no evident cell destruction discovered. 
a

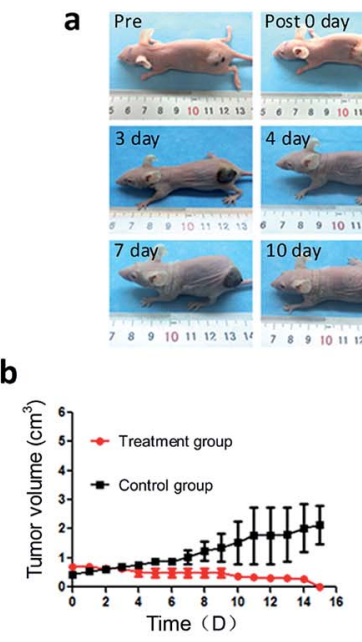

b
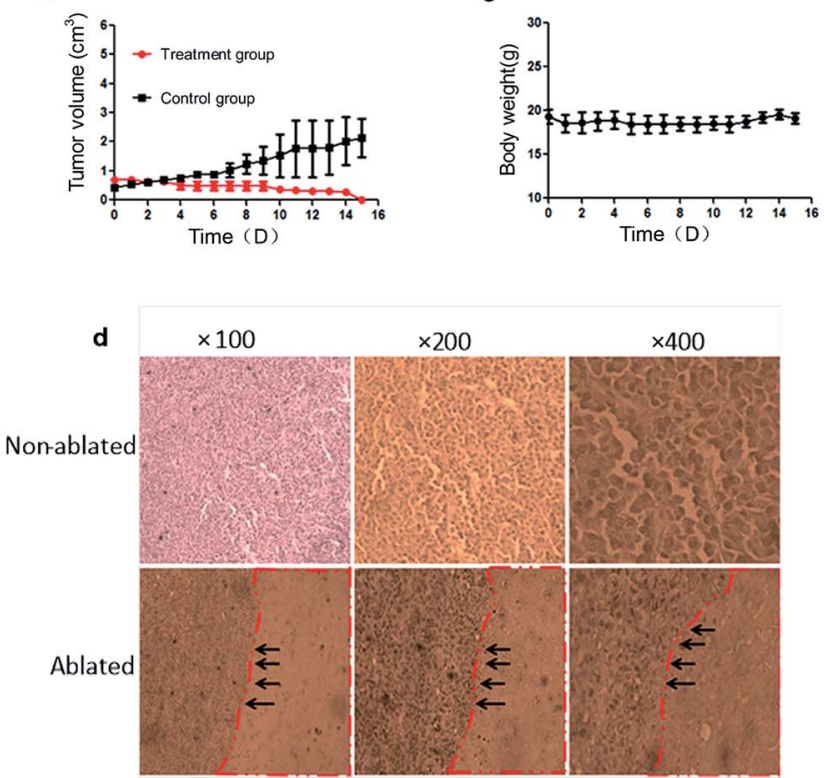

Fig. 6 (a) The macroscopic images showed the change of tumor volume within 15 days after the magnetic hyperthermia ablation; (b) the time-tumor volume curve; (c) the time-body weight curve; (d) the $\mathrm{HE}$ staining of the non-ablated and ablated tumor tissue (red dotted line: the ablated tissue, black arrow: boundary between ablated tissue and non-ablated tissue).

\section{Discussion}

In this study, we prepared an injectable, fast liquid to solid phase transitional material, the $\mathrm{PMMA}-\mathrm{Fe}_{3} \mathrm{O}_{4}$, and confirmed its high efficiency for the magnetic hyperthermia therapy of tumor in vivo.

The results showed that the $\mathrm{Fe}_{3} \mathrm{O}_{4}$ nanoparticles could be uniformly distributed inside the PMMA, which was thought to be the underneath reason for the relatively high compressive strength of PMMA- $\mathrm{Fe}_{3} \mathrm{O}_{4}{ }^{25}$ When the PMMA- $\mathrm{Fe}_{3} \mathrm{O}_{4}$ contacted with water, it could keep integrated and form a solid implant after the setting time. The setting time of PMMA was found to be significantly shorter than the reported setting time of CPC. The PMMA- $\mathrm{Fe}_{3} \mathrm{O}_{4}$ could transform from liquid to solid rapidly. Thus, $\mathrm{Fe}_{3} \mathrm{O}_{4}$ nanoparticles were quickly trapped inside the implant, which means PMMA- $\mathrm{Fe}_{3} \mathrm{O}_{4}$ could well confine the $\mathrm{Fe}_{3} \mathrm{O}_{4}$ nanoparticles inside the tumor decreasing the risk of leaking to the surrounding tissue or blood vessel. The hysteresis curve of $\mathrm{Fe}_{3} \mathrm{O}_{4}$ powder and PMMA-10c powder showed that both of them were ferromagnetic, while the $\mathrm{Fe}_{3} \mathrm{O}_{4}$ had a much higher $M_{\mathrm{s}}$ value and Oe value. As we know, the heat-generating ability of ferromagnetic materials is positively correlated to the magnitude of the coercive force of ferromagnetic materials and the alternating current magnetic field strength. ${ }^{30}$ Briefly, if the coercive force of the $\mathrm{Fe}_{3} \mathrm{O}_{4}$ is bigger than the applied magnetic field, then no heat would be generated by $\mathrm{Fe}_{3} \mathrm{O}_{4}$. The heating efficiency in vitro showed that the surface temperature and coagulation necrosis area of tissue were positively correlated to the time and the iron contents, which suggested that temperature and ablated area could be controlled to further improve its efficiency and safety. After heating, the PMMA-10c could still keep its integrity, which was different from the other reported magnetic materials which had a melting phenomenon after heating. Thus, PMMA-10c might be able to be repeated used for the magnetic ablation of residue tumor or reoccurrence tumor. Furthermore, the PMMA-10c was visible under real time ultrasound imaging which guaranteed the precisely injection of PMMA-10c inside the tumor, which further improved its efficiency for the completely ablation of tumor.

Interestingly, we found the ablated area of tumor was larger than the ablated area of the excised bovine liver using the same magnetic field at the same time. The reason might be that the tumor tissue was more sensitive to heat than the normal liver tissue.

For the bench to bed translation of this novel material, the safety issue of PMMA-10c should be concerned. The PMMA-10c was composed of PMMA and $\mathrm{Fe}_{3} \mathrm{O}_{4}$ nanoparticles. PMMA has been reported as a safe and biocompatible bone cement which has been used in clinic more than 50 years, especially for percutaneous vertebroplasty (PVP) and percutaneous kyphoplasty (PKP). ${ }^{31,32}$ On the other hand, $\mathrm{Fe}_{3} \mathrm{O}_{4}$ nanoparticles, as a magnetic resonance imaging (MRI) contrast agent, have been authorized by the FDA for clinical application. ${ }^{33}$ They are biodegradable in vivo and can be assimilated by physiological metabolism. ${ }^{34}$ Thus, we think the PMMA-10c should inherit their good safety properties. While more studies on safety, such as long-term toxicity study, need to be performed in future.

The efficiency of the injectable and phase transitional PMMA$\mathrm{Fe}_{3} \mathrm{O}_{4}$ was proved in vivo in this study for the hyperthermia therapy of tumor. However, there are some limitations in this study as well, which need to be further studied. Firstly, only the surface temperature of the skin on the tumor was measured by a far-infrared thermometer, which should be lower than the temperature inside the tumor. The MR thermometry or other non-invasive methods might be useful for the measurement of the internal temperature of the tumor. Secondly, like the other minimally invasive techniques, the magnetic hyperthermia technique will also face the residual tumor problem if the tumor is too large or the magnetic materials are not homogeneously distributed inside the tumor. To combine the magnetic hyperthermia with chemotherapy might be a very good choice since the increased temperature should double the efficiency of chemotherapy to prevent the tumor from reoccurrence. ${ }^{35}$

\section{Conclusion}

The injectable and fast liquid-solid phase transitional PMMA$\mathrm{Fe}_{3} \mathrm{O}_{4}$ was prepared and its high efficiency for tumor hyperthermia therapy was confirmed in vivo. 


\section{Acknowledgements}

We acknowledge the financial supports from 973 program (No. 2014CB744500), the National Science Foundation for Distinguished Young Scholars (81425014), National Nature Science Foundation of China (No. 81227801, 81270021, 31630026, 81271598, 81571688), Chongqing Fund for Distinguished Young Scholars (cstc2013jcyjjq10004), Program for New Century Excellent Talents in University (NCET-13-1067).

\section{References}

1 R. L. Siegel, K. D. Miller and A. Jemal, Ca-Cancer J. Clin., 2016, 65, 5-29.

2 A. Jemal, F. Bray, M. M. Center, J. Ferlay, E. Ward and D. Forman, Ca-Cancer J. Clin., 2011, 61, 69-90.

3 R. Siegel, D. Naishadham and A. Jemal, Ca-Cancer J. Clin., 2013, 63, 11-30.

4 D. Li, J. Kang, B. J. Golas, V. W. Yeung and D. C. Madoff, Cancer Biol. Med., 2014, 11, 217-236.

5 R. W. Habash, R. Bansal, D. Krewski and H. T. Alhafid, Crit. Rev. Bioeng., 2006, 34, 491-542.

6 Y. X. Yi, Y. F. Zhang, Q. Wei, L. Zhao, J. B. Han, Y. Song, Y. Ding, G. L. Lu, J. M. Liu, H. Y. Ding, F. Dai and X. J. Tang, Chin. J. Cancer Res., 2014, 26, 112-118.

7 C. J. Gannon, C. R. Patra, R. Bhattacharya, P. Mukherjee and S. A. Curley, J. Nanobiotechnol., 2008, 6, 1-9.

8 J. Van der Zee, Ann. Oncol., 2002, 13, 1173-1184.

9 S. Garca-Jimeno, R. Ortega-Palacios, M. Cepeda-Rubio, A. Vera, L. Leija and J. Estelrich, Prog. Electromagn. Res., 2012, 128, 229-248.

10 M. Mohamed, G. Borchard and O. Jordan, J. Drug Delivery Sci. Technol., 2012, 22, 393-408.

11 M. Johannsen, U. Gneveckow, L. Eckelt, A. Feussner, N. Waldofner, R. Scholz, S. Deger, P. Wust, S. A. Loening and A. Jordan, Int. J. Hyperthermia, 2005, 21, 637-647.

12 B. Thiesen and A. Jordan, Int. J. Hyperthermia, 2008, 24, 467474.

13 S. Laurent, S. Dutz, U. O. Hafeli and M. Mahmoudi, Adv. Colloid Interface Sci., 2011, 166, 8-23.

14 J. Rehman, J. Landman, R. D. Tucker, D. G. Bostwick, C. P. Sundaram and R. V. Clayman, J. Endourol., 2002, 16, 523-531.

15 M. Latorre and C. Rinaldi, P. R. Health Sci. J., 2009, 28, 227238.

16 M. Babic, M. Schmiedtova, R. Poledne, V. Herynek and D. Horak, J. Biomed. Mater. Res., Part B, 2015, 103, 11411148.

17 A. H. El-Sayed, A. A. Aly, N. I. EI-Sayed, M. M. Mekawy and A. A. EI-Gendy, J. Mater. Sci.: Mater. Med., 2007, 18, 523-528. 18 C. Y. Xu, Y. Y. Zheng, W. Gao, J. X. Xu, G. Q. Zuo, Y. Chen, M. Z. Zhao, J. B. Li, J. L. Song, N. Zhang, Z. G. Wang,
H. Y. Zhao and Z. C. Mei, ACS Appl. Mater. Interfaces, 2015, 7, 13866-13875.

19 M. H. Zhang, K. Sisomphon, T. S. Ng and D. J. Sun, Construct. Build. Mater., 2010, 24, 1700-1707.

20 D. T. Felson and J. J. Anderson, Lancet, 1987, 329, 902-906.

21 S. Nouda, S. Tomita, A. Kin, K. Kawahara and M. Kinoshita, Spine, 2009, 34, 2613-2618.

22 M. Jager and A. Wilke, J. Biomater. Sci., Polym. Ed., 2003, 14, 1283-1298.

23 A. J. Evans, M. E. Jensen, K. E. Kip, A. J. DeNardo, G. J. Lawler, G. A. Negin, K. B. Remley, S. M. Boutin and S. A. Dunnagan, Radiology, 2003, 226, 366-372.

24 W. F. Mousa, M. Kobayashi, S. Shinzato, M. Kamimura, M. Neo, S. Yoshihara and T. Nakamura, Biomaterials, 2000, 21, 2137-2146.

25 M. Kawashita, K. Kawamura and Z. Li, Acta Biomater., 2010, 6, 3187-3192.

26 K. Goto, J. Tamura, S. Shinzato, S. Fujibayashi, M. Hashimoto, M. Kawashita, T. Kokubo and T. Nakamura, Biomaterials, 2005, 26, 6496-6505.

27 M. Starowicz, P. Starowicz, J. Zukrowski, J. Przewoznik, A. Lemanski, C. Kapusta and J. Banas, J. Nanopart. Res., 2011, 13, 7167-7176.

28 Y. Chen, L. Jiang, R. Wang, M. Lu, Q. Zhang, Y. Zhou, Z. G. Wang, G. M. Lu, P. Liang, H. T. Ran, H. R. Chen and Y. Y. Zheng, Adv. Mater., 2014, 26, 7468-7473.

29 S. Naito, A. Eschenbach, R. Giavazzi and I. Fidler, Cancer Res., 1986, 46, 4109-4115.

30 T. Atsumi, B. Jeyadevan, Y. Sato and K. Tohji, J. Magn. Magn. Mater., 2007, 310, 2841-2843.

31 K. Goto, J. Tamura, S. Shinzato, S. Fujibayashi, M. Hashimoto, M. Kawashita, T. Kokubo and T. Nakamura, Biomaterials, 2005, 26, 6496-6505.

32 P. Bourrinet, H. H. Bengele, B. Bonnemain, A. Dencausse, J. M. Idee, P. M. Jacobs and J. M. Lewis, Invest. Radiol., 2006, 41, 313-324.

33 M. Levy, N. Luciani, D. Alloyeau, V. Deveaux, C. Pechoux, S. Chat, G. Wang, N. Vats, F. Gendron, C. Factor, S. Lotersztajn, A. Luciani, C. Wilhelm and F. Gazeau, Biomaterials, 2011, 32, 3988-3999.

34 L. Lartigue, D. Alloyeau, J. Kolosnjaj-Tabi, Y. Javed, P. Guardia, A. Riedinger, C. Pechoux, T. Pellegrino, C. Wilhelm and F. Gazeau, ACS Nano, 2013, 7, 3939-3952.

35 R. D. Issels, L. H. Lindner, P. Wust, P. Reichardt, B. C. Schem, S. Abdel Rahman, S. Daugaard, C. Salat, C. M. Wendtner, Z. Vujaskovic, R. Wessalowski, K. W. Jauch, H. R. Durr, F. Ploner, A. B. Melnyk, U. Mansnann, W. Hiddemann, J. Y. Blay and P. Hohenberger, Lancet Oncol., 2010, 11, 561-570. 